\title{
ASSESSMENT OF STUDENT'S PREFERENCES OF LECTURE DELIVERY METHOD FOR TEACHING GYNAECOLOGY IN MEDICAL GRADUATION
}

\author{
Girish B. L $L^{1}$, Dwarakinath $L^{2}$, Nandagopal K. $M^{3}$, Srinath $S^{4}$, Mahesh $S . H^{5}$, Raghunatha Shivanna ${ }^{6}$, Chitra $R^{7}$, Aslin Benola V8 \\ ${ }^{1}$ Assistant Professor, Department of OBG, Sri Siddhartha Medical College, Agalakote, Tumkur, Karnataka, India. \\ 2 Professor, Department of OBG, Sri Siddhartha Medical College, Agalakote, Tumkur, Karnataka, India. \\ 3 Professor and HOD, Department of OBG, Sri Siddhartha Medical College, Agalakote, Tumkur, Karnataka, India. \\ ${ }^{4}$ Professor, Department of General Surgery, Sri Siddhartha Medical College, Agalakote, Tumkur, Karnataka, India. \\ ${ }^{5}$ Assistant Professor, Department of Community Medicine, Sri Siddhartha Medical College, Agalakote, Tumkur, Karnataka, India. \\ ${ }^{6}$ Professor, Department of Dermatology, Sri Siddhartha Medical College, Agalakote, Tumkur, Karnataka, India. \\ 7 Intern, Department of OBG, Sri Siddhartha Medical College, Agalakote, Tumkur, Karnataka, India. \\ 8Intern, Department of OBG, Sri Siddhartha Medical College, Agalakote, Tumkur, Karnataka, India.
}

\begin{abstract}
BACKGROUND: Classroom lectures have been a teaching tool since ages. The methods of lecture delivery have shifted from conventional black board method to use of overhead projector method and from overhead projector method to PowerPoint presentation. It is observed that the teachers continued using all the three methods due to inherent weakness of each of them, which was complemented by the other.

OBJECTIVE: So the study was done to know the strength and weakness of Blackboard, OHP \& PowerPoint and to make necessary adjustments while delivering gynaecology lectures.

MATERIALS AND METHODS: A cross sectional was done for the final MBBS students, who were taught by Gynaecology by Blackboard, Overhead projector and PowerPoint presentations at various phases of MBBS graduation till final year. The sample size was 86 members in the survey.

OBSERVATIONS AND RESULTS: the organization of lecture ,clarity of lecture, conveying of notes and diagrams were rated better with PowerPoint and OHP (Overhead projector) than Blackboard, but, PowerPoint was better among the two (PPT $>$ OHP > BLACKBOARD). The difference between the three was statistically significant $(\mathrm{p}<0.001)$. Stimulation of interest during lecture, scope for participation of student, more engaging, time to take notes, flexibility to amplify a particular point was better with Blackboard teaching as compared to OHP and PowerPoint. The differences were statistically significant $(\mathrm{p}<0.0001)$.

CONCLUSION: It can be concluded that the specific learning objectives can be achieved only by combination of teaching delivery methods. For effective teaching, as ascertained by this study, integration of Blackboard teaching and PowerPoint presentations is ideal.
\end{abstract}

KEYWORDS: Blackboard, Overhead Projector, Power Point Presentation, Student Preference, Lectures Delivery Method.

HOW TO CITE THIS ARTICLE: Girish B. L, Dwarakinath L, Nandagopal K. M, Srinath S, Mahesh S. H, Raghunatha Shivanna, Chitra R, Aslin Benola V. "Assessment of Student's Preferences of Lecture Delivery Method for Teaching Gynaecology in Medical Graduation". Journal of Evolution of Medical and Dental Sciences 2015; Vol. 4, Issue 89, November 05; Page: 15463-15467, DOI: $10.14260 /$ jemds/2015/2210.

INTRODUCTION: Teaching is a means of facilitating and supporting learning and this involves contingent functions. ${ }^{1}$ Learning is a cognitive process which brings about change in the behaviour of the learner.2,3 Earliest medical education involved watching their masters and obeying their masters in empiric way, not scientifically. 4 This involved apprenticeship system where knowledge was passes on from father physician to son of aspiring student.

One of the earliest description of requirements for a good students was narrated by Charaka (c 500 B C). ${ }^{5}$ It was Galen who stressed upon the need for writing manuals of instruction,

Financial or Other, Competing Interest: None.

Submission 09-10-2015, Peer Review 10-10-2015,

Acceptance 21-10-2015, Published 05-11-2015.

Corresponding Author:

Dr. Girish B. L,

Assistant Professor,

Department of $O B G$,

Sri Siddhartha Medical College, Agalakote,

Tumkur-572107, Karnataka, India.

E-mail:drgirish_bylake@yahoo.com

DOI: $10.14260 /$ jemds $/ 2015 / 2210$. based on which the roman emperors opened medical schools offering lectures and practices related to dissection. ${ }^{6}$

Thomas Sydenham (1624-1689) and John Locke(16321704) made a distinctive mark on medical education emphasising the importance of medical theory and medical practicals. ${ }^{7}$ As more and more medical science and college evolved worldwide, licencing system, curriculum and examination system evolved thought the world. ${ }^{8}$

Lecturing has been one of the oldest methods of teaching since historical times. It is described as the formal presentation of content by educator for subsequent learning and recall in examination by students. ${ }^{9}$

There has been gradual evolution of lecture delivery methods from Black board teaching to Overhead projector and from Overhead projector to PowerPoint with progressive invention of technology.

Looking at various studies conducted earlier, it is clear all the three methods have stayed on as a method for lecture delivery for their inherent advantages and disadvantages.

Students evaluation of lectures have been fundamental in improving teaching methodology and teaching skills. Also student satisfaction is linked to effective teaching. ${ }^{10,11}$ 
So, this study was conducted to know the particular strength and weakness different lecture delivery method while delivery of gynaecological lectures.

MATERIALS AND METHODS: A cross sectional study was done in a medical college, involving final year students. The students were taught Gynaecology at various phases of MBBS. The number of students in this study was 86. A questionnaire bases study was conducted using 10 parameters of a lecture. All the three lecture delivery methods, under study, namely Blackboard, OHP, and PowerPoint were assessed for same parameters. Each parameter, across the three lecture delivery method was assessed by a scoring system.

\section{The 10 parameters included were as follows:}

1. Good organization of lecture

2. Clarity of lecture.

3. Stimulation of interest.

4. More engaging.

5. Scope for student participation.

6. Conveying of notes.

7. Conveying of diagrams.

8. Time for taking down notes and diagrams.

9. Relaxation during lecture.

10. Flexiblity to amplify a particular point.

\section{Scoring system was as, shown below:}

\begin{tabular}{|c|c|}
\hline Strongly disagree & -2 score \\
\hline Disagree & -1 score \\
\hline No opinion & 0 score \\
\hline Agree & 1 score \\
\hline Strongly agree & 2 score \\
\hline
\end{tabular}

At the end of survey sheet, space for comments was given. The students were asked to comment on the reason for particular grading and were asked about advice to improve teaching and learning.

\section{RESULTS: (TABLE 1)}

1. Organisation of lecture: 74 students strongly agreed PPT was good, 3 in OHP and 11 in blackboard. Also 43 disagreed with Blackboard .Chi square value was 307. P value $<0.0001$

2. Clarity of lecture: 49 students strongly agreed PPT was better. The same was 5 and 8 with OHP and Blackboard respectively. Also 49 disagreed with blackboard. Chi square value was 217.8. $P$ value $<0.001$

3. Stimulation of Interest: 28 strongly agreed and 52 agreed with PPT. 30 agreed and 39 had no opinion in OHP group. 64 strongly agreed and 20 agreed in Blackboard group. Chi square value was 154.3. P value $<0.0001$.

4. Scope for Students Participation: 40 disagreed with PPT. 42 disagreed with OHP. 65 strongly agreed with Blackboard. Chi square value was162.6. $\mathrm{p}$ value $<0.0001$

5. More Engaging: 54 agreed with PPT and 34 had no opinion with OHP. 68 strongly agreed with Blackboard.
6. Conveying of Notes: 55 strongly agreed PPT conveyed good notes. 57 just agreed with OHP. 33 disagreed with blackboard. Chi square value was 133.9.P value $<0.0001$.

7. Conveying of Diagram: 81 strongly agreed that PPT conveyed diagrams well.66 just agreed with 0HP.45 disagreed with Blackboard.

8. Time for taking Notes and Diagrams:18 strongly agreed and 28 just agreed that PPT gave enough time to take notes. 29 agreed and 32 had no opinion with OHP. 26 strongly agreed and 38 agreed with Blackboard. Chi square value was 29.85. $P$ value $<0.0001$

9. Relaxation during Lecture: 48 strongly agreed that they relaxed more during PPT lecture. 44 just agreed with OHP. 49 strongly disagreed that they could relax with Blackboard teaching. Chi square value was 178.6.p value $<0.0001$.

10. Flexibility to Amplify a particular Point: 34 just agreed with PPT .46 students had no opinion with OHP. 50 students strongly agreed with Blackboard teaching. Chi square value was 141.3.P value<0.0001.

DISCUSSION: Benjamin Blooms taxonomy of learning objectives involves three domains. They include cognitive, affective and psychomotor domains. The lecture method of teaching mainly deals with the cognitive aspects of learning and lesser levels of affective and psychomotor domains. ${ }^{12}$ Lectures are form of teaching method used since historical times. Various methods of lecturing has been used, which includes didactic lectures, role playing, case studies, demonstration through videotape problem based learning. ${ }^{13}$ Didactic lecture method has been critical for being lecturer dominant and one sided and monotonous. ${ }^{14-15}$

Lectures remain mainstay of medical education because of its ease and convenience to impart education to large numbers of student even with limited resources. This applies to Asian school, where the number of students in a given classroom are large and resources are limited. ${ }^{16,17}$ It also explains the reasons why many studies have been conducted by Asian researchers regarding superiority of lecture delivery method.

The precursor to blackboard teaching has been the use of clay tablets and personal slates by the Sumerians and Babylonians in ancient times and the Indians in $11^{\text {th }}$ century and gradually moved on to blackboard teaching. ${ }^{18}$

With advent of Overhead projector (OHP) in 1960s the student and teachers, suddenly found that clarity of notes, good organisation of lecture, display of notes and diagrams were more appealing and attention drawing than blackboard teaching.

In blackboard teaching, the clarity of writing, especially on repeated cleaning and writing was poor, dusty, pictures were unclear or the teachers avoided drawing difficult pictures thereby making understanding difficult. ${ }^{19}$ The present study also revealed that the students were annoyed with poor organisation of lecture, lack of clarity of writing and display of diagrams with blackboard.

The effectiveness of teaching on OHP depended on quality of sheets prepared by the lecturer, amount of material on a single sheet, font size, availability of electricity. ${ }^{20,21}$ This study also found out OHP lectures were less engaging, and could not take notes and diagrams, as in contrast to blackboard teaching. 
But in some studies student could follow well and take down notes better with OHP.19,20 In the present study, the ratings for Overhead projector (OHP) were seen between Blackboard and Power Point for, clarity of written material, good organisation of lecture, conveying of notes and diagrams. So a Power Point presentation fully replaces OHP for the same parameters having advantages, when compared to Blackboard. With the advent of PowerPoint software and increased availability of internet, lecturers were able to prepare attractive material.

The ability to display three dimension pictures, animations and videos, which is almost required in all specialities of medicine, created excitement among both teachers and students alike.19,22,23 The present study revealed that, PowerPoint was the best in organisation of lecture, clarity of lecture, conveying of notes and diagram, when compared to OHP and Blackboard.

However there were complaints that there was less interaction, no time to take notes and diagrams, as lectures were hurried about.19,23 Additionally, along with the aforementioned complaints, this study also found that there was no flexibility of a particular point. Finally the students found something missing in PowerPoint which was seen in blackboard teaching. The blackboard teaching possessed features that lacked in Power Point presentations. Blackboard teaching was slow paced, drew the attention of the students to give time to think, take down notes and diagrams.

There was better interaction between teacher and the learner.19,22,24 We also noted in this study that blackboards were more engaging, interesting, student had more time to take notes, and there was flexibility for amplifying a particular point.

In some studies, preferred Power Point presentations better, but when objective testing was done Blackboard taught performed better in scoring marks than Power Point taught students, and also Power Point presentations fared better than OHP.19,25,26 However other studies found Power Point better in scoring marks. ${ }^{27}$

The student in the comment section, of this study, wrote that, integration of Power Point and blackboard was better than using any single method for teaching. PowerPoint supplemented those parameters which were lacking in blackboard and vice-versa. It was concluded by many studies that integrated teaching involving Blackboard and Power Point presentations was most preferred for better learning. ${ }^{19,28,29}$

CONCLUSION: Teaching and learning involves a human element and complement of technology for fulfilment of the educational objectives. It can been seen that there is conflict of preferences of lecture delivery method in various studies done reflecting the characteristics of teacher, teaching method and the heterogeneity of ability of learning capacity by different student.

Consensus of many studies advocates integration of Blackboard and Power Point presentations for better teaching and learning. Even, this study comes to the same conclusion with regards to teaching in gynaecology. So customisation of teaching method is order of the day, in the present.

\section{REFERENCES:}

1. Squires G. A framework of teaching.Br J Educ Stud. 2004;52:342-58

2. Ormrod J E, editor. Human learning. $3^{\text {rd }}$ ed. Sydney: Prentice Hall;1999.

3. Chadwick S M, Bearn D R. Teaching and learning: An update for orthodontist. J Orthodont 2002;29:162-7.

4. Taylor, A .E. The Laws of Plato Translated into English.London.1934.

5. Lakshmi Pathi, A. (1944).A Textbook of Ayurveda, vol.1.Bezwada,India.

6. Drabkin I E. Bull. Hist. Med.1994;15,333.

7. Newman, G. Some Notes on Medical Education in England. A memorandum addressed to the president of the board. Great Britain, Board of Education.London.1918;page 21.

8. Fulton, J. F. History of Medical Education.Br Med Jounal.1953;Aug 29: page 457-61

9. Vella F. Medical education: Capitalising on the lecture method. FASEB J.1992;6(3):811-812.

10. Theall $\mathrm{M}$, Abrami $P \mathrm{C}$ and Mets $\mathrm{L} A$. The student ratings debate: Are they valid? How can we best use them? New directions for institutional research, 2001;109,9-25,San Francisco, Ca: Jossey-Bass.

11. Franklin J. Interpreting the numbers: using a narrative to help other student evaluations of your teaching accurately. In K. G Lewis(Ed.) Techniques and stratergies for interpreting student evaluation. New Directions for Teaching and Learning.2001;87:85-99.San Francisco Ca:Jossey-Bass

12. Bloom ,B. S.;Engelhart M. D.;Furst, E J.; Hill, W H.; Krathwohl D. R. Taxonomy of education objection: The classification of educational objectives: the classification of educational goals. Handbook 1:cognitive domain.1956;New York:David McKay Company

13. Ramsden P. Learning to teach in higher education. London, Routledge: Psychology Press1992.

14. Kizlik B. Instructional methods information: part 1.2012;available on

http://www.adprima.com/teachmeth.htm.accessed on 1st oct 2015

15. Deleaney JG, Johnson AN, Johnson TD, Treslan DL. Students perceptions of effective teaching in higher education.2010;available at www.uwex.edu/disted/conference/resource./28251 10H.pdf.accessed on $1^{\text {st }}$ oct 2015

16. Papanna KM, Kulkarni V, Tanvi D, Lakshmi V, Kriti L, Unnikrishnan B, Akash S, Tejesh S, Sumit kumar S. Perceptions and preferences of medical students regarding teaching methods in a Medical College, Mangalore, India. Afr Health Sci.2013 sep;13(3):808-813.

17. Stuart J, Rutherford RJD. Medical student concentration during lectures, Lancet 1978;2(8088):514-6

18. Journal of News and Resources for Teachers.(n.d). The History of the Classroom Blackboard. Concordia Universitys Online Education Degrees.Retreived October 1st,2015,from

http:/education.cu-portland edu/blog/referencematerial/the-history-of the classroom-blackboard/ 
19. Vikas Seth, Prerarana Upadhyaya, Mushtaq Ahmed, Virendra Kumar. "Impact of Various Lecture Delivery Methods in Pharmacology". EXCLI Journal;2010 ;9:96101.

20. Shah H K. Overhead projector-A versatile teaching tool. Indian J of Community Med 2006; 31.available from http://www.ind medica.com/journals. php? journaled=7 and issueid $=73 \&$ articleid $=942 \&$ action $=$ article .accessed october1,2015.

21. Moscoe FK. Overhead Projectors and LCD Panels.In Gayeski DM(ed.).Designing Communicating and Learning Environments. New Jersey, Educational Technology Publications, 1995.

22. Meo SA, Shahabuddin S, Al Masri A A, Ahmed SM, Aquil M, Anwar MA and Al-Drees AM.Comparision of the impact of PowerPoint and Chalkboard in undergraduate medical teaching: An evidence based study.J Coll Physicians Surg.Pak. 2013;23(1) :47-50

23. Priyadarshini. K S. H.V. Shetty, Reena. R. Assessment of different teaching aids and teaching Methods for the better perception of Biochemistry by $1^{\text {st }}$ MBBS student. Journal of Evolution of Medical and Dental Sciences.2012;1(6)1159-65.

24. Dhaliwal U.A prospective study of medical students perspective teaching-learning media: reiterating the importance of feedback. J Indian Med Assoc 2007;105(11):621-623
25. Phani Kumar M. Preferences of undergraduate medical students-Electronic and non-electronic teaching methods in pathology. International journal of research in health sciences.2013;1(3):p 239-41

26. Baruah M, Patel L. Evaluation of different teaching methods used in physiology lectures. Indian journal of basic and applied medical research; December 2014;4(1):271-76

27. Gaur $\mathrm{K}$ L. Impact comparison of Chalkboard and PowerPoint Teaching in Medical Education. p@ iisrcinternational journal of information technology and computer science(IJITCS)(http://www.ijites.com) (ISSN:2091-1610), 12 (3)p8

28. Prasanna Chandra M, Biswajit Das M B , Samantha S, Mallick A K.A study of students attitudes towards the use of different types of audiovisual techniques for biochemistry. Research Journal of Pharmaceutical, Biological and Chemical Sciences, 2012;3(2):p 1097-1103

29. Mrinal Pal, Subinay Dutta, Amit Kumar Pradhan, Kanika Mandi Chowdhuri, Joydeep Ghosh, Rajarshri Rahut. Comparison between different Teaching Methods to increase Performance of Students in Biochemistry. TAF Prev Med Bull.2014;13(4):281-288. 


\begin{tabular}{|c|c|c|c|c|c|c|c|c|c|}
\hline \multirow[t]{2}{*}{$\begin{array}{c}\text { Parameters of lecture } \\
\text { delivery }\end{array}$} & & & & & & & & & \\
\hline & & $\begin{array}{l}\text { Strongly } \\
\text { disagree }\end{array}$ & Disagree & $\begin{array}{c}\text { No } \\
\text { opinion }\end{array}$ & Agree & $\begin{array}{l}\text { Strongly } \\
\text { agree }\end{array}$ & $n=86$ & $\begin{array}{l}\text { Chi Sq } \\
\text { Value }\end{array}$ & $\begin{array}{c}\mathbf{p} \\
\text { value }\end{array}$ \\
\hline \multirow[t]{4}{*}{$\begin{array}{l}\text { 1. Good organisation } \\
\text { of lecture }\end{array}$} & & & & & & & & 307 & $\begin{array}{c}<0.00 \\
01\end{array}$ \\
\hline & BB & 12 & 43 & 15 & 5 & 11 & 86 & & \\
\hline & OHP & 1 & 1 & 14 & 67 & 3 & 86 & & \\
\hline & PPT & 1 & 1 & 1 & 9 & 74 & 86 & & \\
\hline \multirow[t]{4}{*}{ 2. Clarity of lecture } & & & & & & & & 217.8 & $\begin{array}{c}<0.00 \\
01\end{array}$ \\
\hline & BB & 8 & 49 & 12 & 9 & 8 & 86 & & \\
\hline & OHP & 1 & 0 & 34 & 46 & 5 & 86 & & \\
\hline & PPT & 1 & 0 & 4 & 32 & 49 & 86 & & \\
\hline \multirow[t]{4}{*}{$\begin{array}{l}\text { 3. Stimulation of } \\
\text { interest }\end{array}$} & & & & & & & & 154.3 & $\begin{array}{c}<0.00 \\
01\end{array}$ \\
\hline & $\mathrm{BB}$ & 1 & 1 & 0 & 20 & 64 & 86 & & \\
\hline & OHP & 1 & 13 & 39 & 30 & 3 & 86 & & \\
\hline & PPT & 0 & 4 & 2 & 52 & 28 & 86 & & \\
\hline \multirow[t]{4}{*}{$\begin{array}{l}\text { 4. Scope for students } \\
\text { participation }\end{array}$} & & & & & & & & 162.6 & $\begin{array}{c}<0.00 \\
01\end{array}$ \\
\hline & BB & 1 & 0 & 2 & 18 & 65 & 86 & & \\
\hline & OHP & 5 & 42 & 16 & 21 & 2 & 86 & & \\
\hline & PPT & 6 & 40 & 8 & 27 & 5 & 86 & & \\
\hline \multirow[t]{4}{*}{ 5. More engagement } & & & & & & & & & $\begin{array}{c}<0.00 \\
01\end{array}$ \\
\hline & BB & 0 & 0 & 0 & 18 & 68 & 86 & & \\
\hline & OHP & 3 & 20 & 34 & 25 & 4 & 86 & & \\
\hline & PPT & 2 & 9 & 7 & 54 & 14 & 86 & & \\
\hline \multirow[t]{4}{*}{$\begin{array}{l}\text { 6. Good conveyance } \\
\text { of notes }\end{array}$} & & & & & & & & 133.9 & $\begin{array}{c}<0.00 \\
01\end{array}$ \\
\hline & $\mathrm{BB}$ & 5 & 33 & 17 & 15 & 16 & 86 & & \\
\hline & OHP & 1 & 2 & 22 & 57 & 4 & 86 & & \\
\hline & PPT & 0 & 0 & 3 & 28 & 55 & 86 & & \\
\hline \multirow[t]{4}{*}{$\begin{array}{l}\text { 7. Conveyance of } \\
\text { diagrams }\end{array}$} & & & & & & & & & $\begin{array}{c}<0.00 \\
01\end{array}$ \\
\hline & BB & 13 & 45 & 12 & 12 & 4 & 86 & & \\
\hline & OHP & 1 & 0 & 11 & 66 & 8 & 86 & & \\
\hline & PPT & 0 & 0 & 0 & 5 & 81 & 86 & & \\
\hline \multirow[t]{4}{*}{$\begin{array}{l}\text { 8. Enough time for } \\
\text { taking notes }\end{array}$} & & & & & & & & 29.85 & $\begin{array}{c}<0.00 \\
01\end{array}$ \\
\hline & BB & 3 & 7 & 12 & 38 & 26 & 86 & & \\
\hline & OHP & 3 & 16 & 32 & 29 & 6 & 86 & & \\
\hline & PPT & 1 & 22 & 17 & 28 & 18 & 86 & & \\
\hline \multirow[t]{4}{*}{$\begin{array}{c}\text { 9.Good relaxation } \\
\text { during lecture }\end{array}$} & & & & & & & & 178.6 & $\begin{array}{c}<0.00 \\
01\end{array}$ \\
\hline & BB & 49 & 30 & 2 & 2 & 3 & 86 & & \\
\hline & OHP & 0 & 12 & 28 & 44 & 2 & 86 & & \\
\hline & PPT & 0 & 1 & 6 & 31 & 48 & 86 & & \\
\hline \multirow[t]{4}{*}{$\begin{array}{l}\text { 10. Flexiblity to } \\
\text { amplify a } \\
\text { particular point }\end{array}$} & & & & & & & & 141.3 & $\begin{array}{c}<0.00 \\
01\end{array}$ \\
\hline & BB & 1 & 0 & 2 & 33 & 50 & 86 & & \\
\hline & OHP & 1 & 24 & 46 & 12 & 3 & 86 & & \\
\hline & PPT & 6 & 22 & 18 & 34 & 6 & 86 & & \\
\hline \multicolumn{10}{|c|}{ Table 1: Preferences of teaching methods } \\
\hline
\end{tabular}

